\title{
Study of the serotonin transporter (SLC6A4) and $B D N F$ genes in French patients with non syndromic mental deficiency
}

\author{
Refaat Tabagh', Christian R Andres ${ }^{1,2}$, Sylviane Védrine ${ }^{1}$, Catherine Cherpi-Antar', Rose-Anne Thepault ${ }^{1}$, \\ Laurence Mignon ${ }^{3}$, Diane Dufour-Rainfray', Claude Moraine ${ }^{1}$, Patrick Vourc' $h^{1,2^{*}}$
}

\begin{abstract}
Background: Mental deficiency has been linked to abnormalities in cortical neuronal network connectivity and plasticity. These mechanisms are in part under the control of two interacting signalling pathways, the serotonergic and the brain-derived neurotrophic (BDNF) pathways. The aim of the current paper is to determine whether particular alleles or genotypes of two crucial genes of these systems, the serotonin transporter gene (SLC6A4) and the brain-derived neurotrophic factor gene (BDNF), are associated with mental deficiency (MD).

Methods: We analyzed four functional polymorphisms (rs25531, 5-HTTLPR, VNTR, rs3813034) of the SLC6A4 gene and one functional polymorphism (Val66 Met) of the BDNF gene in 98 patients with non-syndromic mental deficiency (NS-MD) and in an ethnically matched control population of 251 individuals.

Results: We found no significant differences in allele and genotype frequencies in the five polymorphisms studied in the SLC6A4 and BDNF genes of NS-MD patients versus control patients. While the comparison of the patterns of linkage disequilibrium ( $\left.D^{\prime}\right)$ in the control and NS-MD populations revealed a degree of variability it did not, however, reach significance. No significant differences in frequencies of haplotypes and genotypes for VNTR/ rs3813034 and rs25531/5-HTTLPR were observed.

Conclusion: Altogether, results from the present study do not support a role for any of the five functional polymorphisms of SLC6A4 and BDNF genes in the aetiology of NS-RM. Moreover, they suggest no epistatic interaction in NS-MD between polymorphisms in BDNF and SLC6A4. However, we suggest that further studies on these two pathways in NS-MD remain necessary.
\end{abstract}

\section{Background}

Mental deficiency (MD) is defined as an intelligence quotient (IQ) below 70 with impairments in social skills, self-care, and work. The prevalence of non-syndromicMD (NS-MD) in developed countries is higher than $0.5 \%[1,2]$. A large proportion of NS-MD cases results from abnormalities in neuronal network connectivity and plasticity, and these require particular neurotrophic factors and neurotransmitters for proper establishment and functioning [3].

Serotonin (5-hydroxytryptamine, 5-HT) is a major neurotransmitter involved in several complex behaviours, including cognition and emotion, which have

\footnotetext{
* Correspondence: vourch@med.univ-tours.fr

'UMR Inserm U930, Université François Rabelais de Tours, Tours, France
}

been shown to be altered in NS-MD [4]. Pharmacological and genetic studies also support a role for serotonin in corticogenesis, and brain development in general, even prior to the formation of synapses [5-8]. One key regulator of serotonin levels in the cortex and hippocampus is the serotonin transporter (5-HTT), which is involved in the reuptake of extracellular serotonin $[9,10]$. 5-HTT is a $\mathrm{Na}^{+} / \mathrm{Cl}^{-}$dependant membrane transporter encoded by the $S L C 6 A 4$ gene (solute carrier family 6 member $4 ; 17 q 11.2$ ) (Figure 1) [11]. A polymorphism (5HTTLPR) in the promoter region of SLC6A4 determines the neuroanatomical size and functional coupling of the amygdala-frontal cortical circuit in humans $[12,13]$. This circuit has been implicated in several psychiatric disorders including Fragile $\mathrm{X}$ and 
Williams syndrome, two pathologies characterized by mental deficiency $[14,15]$.

The expression level of 5-HTT is affected by several polymorphisms in the $S L C 6 A 4$ gene (Figure 1). In the promoter region, both the rs 25531 polymorphism (SNP $\mathrm{A} / \mathrm{G}$ ), which is part of a putative binding domain for the AP2 transcription factor, and the 5HTTLPR polymorphism (deletion/insertion) influence the expression levels of 5HTT [16,17]. A neurophysiological imaging study in humans described an association between 5-HTTLPR and prefrontal cortex-limbic excitability, supporting a relation between 5 -HTT and cognitive processing $[18,19]$. 5HTT expression can also be affected by a variable number of tandem repeats (VNTR) in intron 2 and a SNP (rs3813034) in the 3'UTR of the SLC6A4 gene $[20,21]$.

The function of 5HTT is modulated by brain-derived neurotrophic factor (BDNF) as confirmed by experiments on BDNF-deficient mice [22,23]. BDNF, a member of the growth factor family of neurotrophins, contributes to the activity-dependent synaptic development and survival of serotonergic neurons $[9,24]$. In general, BDNF is known to have crucial roles during brain development as well as in adults by regulating synaptic transmission and plasticity. Indeed, modulation of BDNF expression in mice affects synaptic vesicle functioning and plasticity, leading to defects in spatial learning [25]. The secreted protein, BDNF, is encoded by the $B D N F$ gene located at $11 \mathrm{p} 13$ (Figure 1) [26]. The SNP rs6255 (Val66 Met) in this gene affects the activitydependent secretion of BDNF as well as short-term episodic memory in humans $[27,28]$.

When combined with the observation of abnormal serotonin and BDNF blood concentrations in several subjects with NS-MD, the evidence presented thus far suggets that the serotonergic and BDNF signalling systems may be implicated in the aetiology of NS-MD

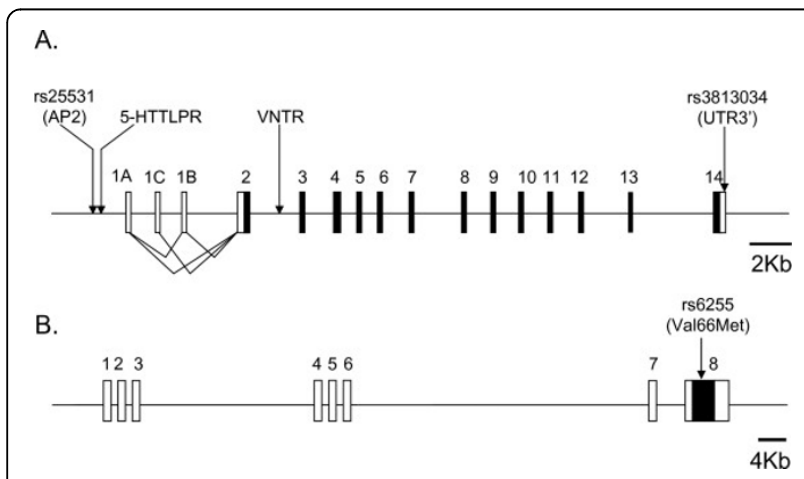

Figure 1 Schematic structure of the human SLC6A4 (A) and BDNF (B) genes. Non-coding and coding exons are indicated by white and black boxes, respectively. Locations of the genotyped polymorphisms and alternative splicing are indicated.
[29-31]. We therefore tested this hypothesis by analysing five functional polymorphisms in the SLC6A4 and BDNF genes in patients with NS-MD.

\section{Methods}

\section{Subjects}

The patients with NS-MD $(\mathrm{n}=98 ; 77$ males and 21 females) were recruited in the genetics unit of the University hospital in Tours (France). All patients showed moderate to severe NS-MD and were submitted to a careful clinical examination, searching for specific signs of the NS-MD syndrome. The patients had no familial history of MD and were therefore considered sporadic. All were negative for fragile $\mathrm{X}$ mutation (FRAXA). The control group $(\mathrm{n}=251)$ consisted of anonymous and unrelated French Caucasian individuals without MD. DNA was extracted from peripheral blood sample using a standard protocol. All patients or parents gave their informed consent.

\section{Genotyping}

The rs25531 and 5-HTTLPR in SLC6A4 were analyzed by RFLP as described in Wendland et al. [32]. The PCR amplification step allowed to differentiate between the short (S, $484 \mathrm{bp})$ versus the long allele (L, $528 \mathrm{bp}$ ) of 5HTTLPR. The restriction step using HpaII enzyme (Biolabs) permitted to identify the alleles (A/G) of rs25531, located 19 bp upstream of 5-HTTLPR. Thus, 10 patterns of migration corresponding to 10 genotypes (rs25531/5-HTTLPR) could be identified after electrophoresis on a $2 \%$ agarose gel (all primers and conditions are available upon request).

The VNTR (17 bp variable number of tandem repeats) in SLC6A4 was studied by PCR followed by electrophoresis on $3 \%$ agarose gel stained with ethidium bromide. PCR conditions for the amplification of the 9 (345 bp), 10 (360 bp) and $12(390 \mathrm{bp})$ repeat alleles are described in Cook et al. [33].

The rs3813034 (G/T) in the 3'UTR region of SLC6A4 gene was genotyped by RFLP. PCR was performed on $100 \mathrm{ng}$ of genomic DNA with $125 \mu \mathrm{M}$ of each dNTP, $200 \mathrm{nM}$ of primers, $1.5 \mathrm{mM} \mathrm{MgCl} \mathrm{m}_{2}$ and $0.02 \mathrm{U} / \mu \mathrm{L}$ of Taq DNA polymerase (Invitrogen), before incubation with MseI (Fermentas) and electrophoresis on a $2 \%$ agarose gel.

The rs6255 (G/A) in BDNF was studied by denaturing high performance liquid chromatography (dHPLC, WAVE System $3500 \mathrm{HT}$, Transgenomic). PCR was performed on $100 \mathrm{ng}$ of genomic DNA with $125 \mu \mathrm{M}$ of each dNTP, $200 \mathrm{nM}$ of primers, $1.5 \mathrm{mM} \mathrm{MgCl}_{2}$ and $0.02 \mathrm{U} / \mu \mathrm{L}$ of Taq DNA polymerase (Invitrogen) (Tm: $\left.59^{\circ} \mathrm{C}\right)$. PCR products were denaturated $\left(96^{\circ} \mathrm{C} 5 \mathrm{~min}\right)$ and slowly renaturated $\left(96^{\circ} \mathrm{C}\right.$ to $50^{\circ} \mathrm{C} ; 1^{\circ} \mathrm{C}$ /minute) before analysis by $\mathrm{dHPLC}$ at $60.2^{\circ} \mathrm{C}$. For individuals showing 
only homoduplex formations (G/G or A/A homozygotes), $10 \mu \mathrm{L}$ of PCR were mixed with $10 \mu \mathrm{L}$ of a PCR product (standard) previously analyzed by DNA sequencing (G/G homozygote). The mixture was denaturated, renaturated, and analysed by dHPLC.

\section{Statistical analysis}

Allele and genotype frequencies in patients and controls were compared with a $\chi^{2}$ test. Odds ratios were estimated for alleles and genotypes http://www.hutchon. net/ConfidOR.htm[34]. Linkage disequilibrium (parameter D') between markers was calculated using the software Haploview v.3.32, with the exception of rs25531 and 5HTTLPR polymorphisms for which chromosome phases could be obtained directly. LD patterns were analysed by Spearman rank correlation (Excel) between LD measures.

\section{Results}

Analysis of SLC6A4 polymorphisms in NS-MD

Hardy Weinberg distribution was respected for the four polymorphisms in SLC6A4 in the two populations (not shown). We did not observe a significant association between NS-MD and the rs25531 $\left(\chi^{2}=0.98 ; \mathrm{p}=0.32\right)$, 5-HTTLPR $\left(\chi^{2}=0.07 ; \mathrm{p}=0.79\right)$ VNTR $\left(\chi^{2}=0.51\right.$; $\mathrm{p}=0.47)$, and rs3813034 $\left(\chi^{2}=0.69 ; \mathrm{p}=0.40\right)$ alleles (Figure 1; table 1). Similarly, no significant association was detected between NS-MD and the genotypes of the four polymorphisms (data not shown). The genotyping method used for rs25531 (AP2) and 5-HTTLPR permitted a direct identification of the phased genotypes. Using these phased genotypes, no significant association between NS-MD and a particular haplotype $\left(\chi^{2}=0.99\right.$; $\mathrm{p}=0.61)$ or genotype $\left(\chi^{2}=1.13 ; \mathrm{p}=0.77\right)$ was detected. As $\mathrm{Hu}$ et al. (2006) reported that the GL genotype can

Table 1 Allelic distributions of polymorphisms in SLC6A4 and BDNF genes in the control and NS-MD populations.

\begin{tabular}{|c|c|c|c|c|c|}
\hline \multirow[t]{2}{*}{ Markers } & \multirow[t]{2}{*}{ Alleles } & \multirow[t]{2}{*}{ Controls } & \multirow[t]{2}{*}{ MR patients } & \multicolumn{2}{|c|}{ MR vs Controls } \\
\hline & & & & $\chi^{2}$ & $\mathbf{p}$ \\
\hline \multicolumn{6}{|c|}{ SLC6A4 gene } \\
\hline \multirow[t]{2}{*}{ rs25531 } & A & $308(93.9)$ & $188(95.9)$ & 0.98 & 0.32 \\
\hline & G & $20(6.1)$ & $8(4.1)$ & & \\
\hline \multirow[t]{2}{*}{ 5-HTTLPR } & $L$ & $198(60.4)$ & $116(59.2)$ & 0.07 & 0.79 \\
\hline & S & 130 (39.6) & $80(40.8)$ & & \\
\hline \multirow[t]{3}{*}{ VNTR } & 9 & $4(1.2)$ & $2(1.0)$ & 0.60 & 0.74 \\
\hline & 10 & $113(34.5)$ & 74 (37.8) & & \\
\hline & 12 & $211(64.3)$ & $120(61.2)$ & & \\
\hline \multirow[t]{2}{*}{ rs3813034 } & $\mathrm{T}$ & $187(57.0)$ & $119(60.7)$ & 0.69 & 0.40 \\
\hline & G & $141(43.0)$ & 77 (39.3) & & \\
\hline \multicolumn{6}{|l|}{ BDNF gene } \\
\hline \multirow[t]{2}{*}{ rs6255 } & G & $378(75.2)$ & $129(77.7)$ & 0.40 & 0.53 \\
\hline & $A$ & $124(24.8)$ & 37 (22.3) & & \\
\hline
\end{tabular}

drive 5HTT expression nearly equivalently to any $S$ genotype (AS or GS), we consequently grouped the GL, AS, and GS haplotypes for analysis. However we still did not observe an association between NS-MD and the haplotype $\left(\chi^{2}=0,12 ; \mathrm{p}=0.73\right)$ or genotype $\left(\chi^{2}=1.28 ; \mathrm{p}=\right.$ 0.73) (Table 2). We used pairwise LD measures (D') between adjacent markers to analyse the patterns of LD in the control and NS-MD populations (Figure 2). Comparison of these unrelated populations revealed a degree of variability which, however, did not reach significance (Spearman rank correlation, $r_{s}=0.50 ; p=0.66$ ). We next analyzed the VNTR/rs3813034 haplotypes in the two populations, and again found no significant difference for haplotype $\left(\chi^{2}=3.80 ; p=0.28\right)$ and genotype $\left(\chi^{2}=3.50 ; \mathrm{p}=0.75\right)$ distributions between controls and NS-MD patients (Table 3).

Analysis of the BDNF Val66 Met polymorphism in NS-MD Hardy Weinberg distribution was respected for the alleles of the BDNF gene in the two populations. We developed a rapid genotyping method using dHPLC to analyze the allelic distribution of the rs6255 (Val66 Met) polymorphism in the $B D N F$ gene (Figure 1). A first analysis by dHPLC allowed to identify the heterozygote genotypes (G/A), and a second analysis, in presence of a standard, allowed to discriminate between $\mathrm{G} / \mathrm{G}$ or A/A homozygotes. We did not find a significant association between NS-MD and alleles of the rs6255 polymorph$\operatorname{ism}\left(\chi^{2}=0.40 ; \mathrm{p}=0.53\right)$ (Table 1$)$.

Several studies have suggested a synergistic interaction between the serotonergic and the BDNF signalling

Table 2 Haplotypes and phased genotypes distributions for the rs25531 and 5-HTTLPR polymorphisms in the SLC6A4 gene in control and NS-MD populations.

\begin{tabular}{lrrrr}
\hline AP2, 5-HTTLPR & Controls & MR patients & \multicolumn{2}{c}{ MR vs Controls } \\
\cline { 4 - 5 } & & & $\chi^{2}$ & p \\
\hline Haplotypes (5HTT gene) & $179(54.57)$ & $110(56,12)$ & 0.12 & 0.73 \\
\hline AL & $149(45.43)$ & $86(43,88)$ & & \\
AS, GL, GS &
\end{tabular}

\begin{tabular}{lrrrr}
\multicolumn{1}{l}{ Phased genotypes } & (5HTT gene) & & \\
\hline AL/AL & $45(27.44)$ & $28(28.57)$ & 1.28 & 0.73 \\
AL/AS & $73(44.51)$ & $47(47.96)$ & & \\
AL/GL & $16(9.76)$ & $6(6.12)$ & & \\
AL/GS & $0(0.0)$ & $1(1.02)$ & & \\
Others & $30(18.29)$ & $16(16.33)$ & & \\
& & & & \\
Genotypes (5HTT/BDNF genes) & & \\
\hline AL AL/Nal Val & $19(13.00)$ & $10(12.66)$ & 0.65 & 0.88 \\
AL AL/Nal Met & $21(14.40)$ & $11(13.92)$ & & \\
Others/Nal Val & $59(40.40)$ & $36(45.57)$ & & \\
Others/Nal Met & $47(32.20)$ & $22(27.85)$ & \\
\hline
\end{tabular}




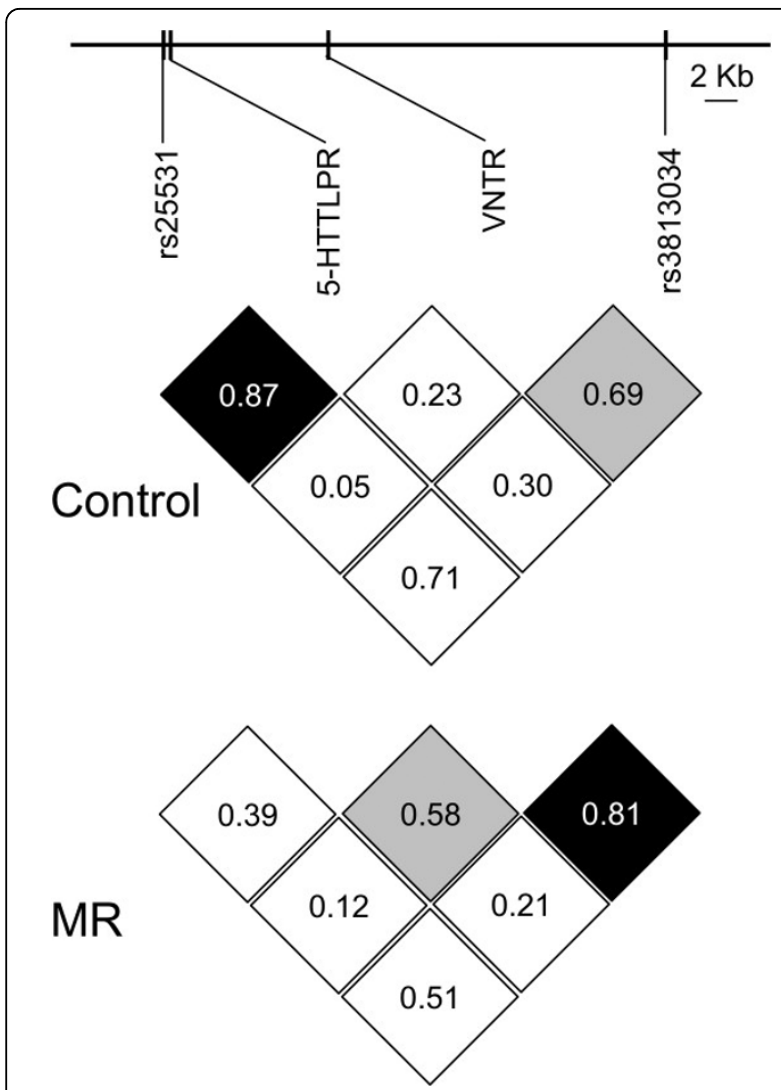

Figure 2 Linkage disequilibrium (LD) map of four polymorphic markers in SLC6A4 gene in control and NS-MD patients. In each square, the normalized linkage disequilibrium measures ( $\left.D^{\prime}\right)$ corresponding to each pair of markers are indicated. Squares are in black if the $D^{\prime}$ values are $\geq 80 \%$ (strong LD) and in grey if the $D^{\prime}$ values are between $50-80 \%$.

Table 3 Haplotypes and genotypes distributions for the VNTR and rs3813034 polymorphisms in the SLC6A4 gene in controls and NS-MD patients.

\begin{tabular}{lrrrr}
\hline VNTR, rs3813034 & Controls & MR patients & \multicolumn{2}{c}{ MR vs Controls } \\
\cline { 5 - 5 } & & & $\chi^{\mathbf{2}}$ & $\mathbf{p}$ \\
\hline Haplotypes & & & & \\
12G & $125(38.1)$ & $70(35.7)$ & 3.8 & 0.28 \\
$12 \mathrm{~T}$ & $85(25.9)$ & $48(24.5)$ & & \\
10T & $99(30.2)$ & $72(36.7)$ & & \\
Others & $19(5.8)$ & $6(3.1)$ & & \\
& & & & \\
Genotypes & & & & \\
12G/10T & $38(23.0)$ & $26(26.2)$ & 3.5 & 0.75 \\
12G/12T & $32(19.8)$ & $17(17.6)$ & & \\
12G/12G & $24(14.5)$ & $13(12.9)$ & & \\
12T/10T & $26(15.7)$ & $17(17.8)$ & \\
12T/12T & $11(6.7)$ & $6(5.99)$ & \\
10T/10T & $15(9.1)$ & $13(13.3)$ & \\
Others & $18(11.2)$ & $6(6.1)$ & \\
\hline
\end{tabular}

systems [35]. We did not observe an association between NS-MD and the 5HTTLPR/rs6255, rs25531 (AP2)/rs6255, or rs3813034/rs6255 genotypes (data not shown). No association was found between NS-MD and a particular combination of AP2-5HTTLPR (AL or others) of the SLC6A4 gene and rs6255 (A or G) of the BDNF gene.

\section{Discussion}

We here report the first genetic study on the serotonin transporter and the brain-derived neurotrophic factor genes in NS-MD. We have investigated five functional polymorphisms in these genes in control individuals and NS-MD patients matched for origin (Central France) and ethnicity (Caucasian).

Power calculations had shown that with the given sample sizes we should be able to detect differences in allelic frequencies of $12 \%$ for 5 -HTTLPR, $12 \%$ for VNTR, 13\% for rs3813034, and 10\% for BDNF rs6255 (alpha of 5\%, power of $80 \%$ ). Functional studies have reported that the $\mathrm{S}$ allele of 5-HTTLPR was associated with a lower expression of 5-HTT and a lower serotonin reuptake activity $[12,36,37]$. Our results do not support a direct role for the $\mathrm{S}$ allele of 5-HTTLPR in NS-MD. Wendland et al. [32] suggested that the effect of 5HTTLPR on SLC6A4 expression may be due to a nearby (19 bp) rs25531 polymorphism in the promoter. The G allele of this polymorphism is located in a consensus binding site for AP2, a family of transcription factors described as positive or negative regulators of transcription [38]. Data from $\mathrm{Hu}$ and colleagues [39] has shown that the $G$ allele of rs25531 was associated with a decreased expression of 5-HTT mRNA compared to the A allele. We did not detect differences in rs 25531 allelic frequencies between NS-MD and control patients. Moreover, we have observed that the frequency of the GS haplotype in both NS-MD and control patients was very low, suggesting that the $G$ allele of rs 25531 was not a risk factor for NS-MD. No statistically significant difference was observed between control and NS-MD patients for genotypes and allelic distributions of the VNTR and rs3813034.

Brain-derived neurotrophic factor (BDNF) is a key regulatory protein of serotonin levels in several brain regions. The pro-BDNF protein is cleaved to form a mature protein before being secreted. The rs6255 polymorphism (Val66 Met), which affects this cleavage, has been associated with impaired hippocampal functioning and decreased scores on the Logical Memory subtest of the Wechsler Memory Scale-Revised [28]. Moreover, Harris et al. [40] have shown that the rs6255 genotype contributes to age-related changes in reasoning skills, which are closely related to general intelligence. Thus, a number of studies support an 
important role for BDNF in cognition processes, and particularly in learning and memory. We did not observe an association between a particular allele or a genotype of rs6255 and French patients with NS-MD. However, it will be interesting to further analyze the complex BDNF locus in neurodevelopmental diseases such as NS-MD. Indeed, recent studies, which have reported a detailed characterization of the $B D N F$ gene locus, have indicated 17 and 13 alternative transcripts for BDNF and anti-BDNF, respectively [41]. AntiBDNF are antisense transcripts expressed from the opposite strand of the BDNF gene [26].

Serotonergic and BDNF signalling systems have significant interactions with overlapping functional targets [30]. Genetic epistasis between these two systems was confirmed by studies on BDNF and SLC6A4 transgenic mice $[23,24]$. In the present study on NS-MD patients we observed no genetic interactions between Val66 Met in $B D N F$ and the four polymorphisms studied in SLC6A4. Particularly, we did not find a relation between the Met allele in BDNF and the S allele in SLC6A4, as described in children with high depressive scores [42]. However, these latter results obtained by Kauffman et al. [42] have been challenged by several studies reporting that the Met allele is protective for anxiety and depression $[43,44]$.

\section{Conclusion}

The present study suggests that the SLC6A4 and BDNF genes have no major effect on the aetiology of NS-MD. Moreover we did not find a gene-by-gene interaction in NS-MD patients between polymorphisms in the $B D N F$ and $S L C 6 A 4$ genes. However, further studies will be necessary to fully reject the implication of SLC6A4 and BDNF in NS-MD. Indeed the expression of these two genes is regulated by epigenetic processes, and these may still be impaired in NS-MD $[45,46]$. Moreover, effects on mRNA splicing, protein localization, and properties of 5-HTT and BDNF could be possible mechanisms for influencing NS-MD risk.

\section{Acknowledgements}

This work was supported by INSERM, Université François Rabelais de Tours, Fondation pour la Recherche Médicale.

\section{Author details \\ 'UMR Inserm U930, Université François Rabelais de Tours, Tours, France. ${ }^{2}$ Laboratoire de Biochimie et Biologie moléculaire, CHRU de Tours, Tours, France. ${ }^{3}$ Neuroscience Education Institute, Carlsbad, CA, USA.}

\section{Authors' contributions}

RT carried out molecular genetic studies and contributed, with $L M$, to manuscript writing. SV, CCA, RAT and DDR participated in the molecular genetic studies. CRA, CM and PV participated in the design and the coordination of the study and manuscript writing. All authors read and approved the final manuscript.

\section{Competing interests}

The authors declare that they have no competing interests.

Received: 23 July 2009

Accepted: 22 February 2010 Published: 22 February 2010

\section{References}

1. Roeleveld N, Zielhuis GA, Gabreels F: The prevalence of mental deficiency: a critical review of recent literature. Dev Med Child Neurol 1997, 39:125-132.

2. Leonard $H$, Wen $X$ : The epidemiology of mental deficiency: challenges and opportunities in the new millennium. Ment Retard Dev Disabil Res Rev 2002, 8:117-134.

3. Dierssen M, Ramakers GJ: Dendritic pathology in mental deficiency: from molecular genetics to neurobiology. Genes Brain Behav 2006, 5(Suppl 2):48-60.

4. Strobel A, Dreisbach G, Muller J, Goschke T, Brocke B, Lesch KP: Genetic Variation of Serotonin Function and Cognitive Control. J Cogn Neurosci 2007.

5. Whitaker-Azmitia PM: Serotonin and brain development: role in human developmental diseases. Brain Res Bull 2001, 56:479-485.

6. Persico AM, Mengual E, Moessner R, Hall FS, Revay RS, Sora I, Arellano J, DeFelipe J, Gimenez-Amaya JM, Conciatori M, Marino R, Baldi A, Cabib S, Pascucci T, Uhl GR, Murphy DL, Lesch KP, Keller F: Barrel pattern formation requires serotonin uptake by thalamocortical afferents, and not vesicular monoamine release. J Neurosci 2001, 21:6862-6873.

7. Gaspar P, Cases O, Maroteaux L: The developmental role of serotonin: news from mouse molecular genetics. Nat Rev Neurosci 2003, 4:1002-1012.

8. Wellman $C L$, Izquierdo A, Garrett JE, Martin KP, Carroll J, Millstein R, Lesch KP, Murphy DL, Holmes A: Impaired stress-coping and fear extinction and abnormal corticolimbic morphology in serotonin transporter knock-out mice. J Neurosci 2007, 27:684-691.

9. Mamounas LA, Altar CA, Blue ME, Kaplan DR, Tessarollo L, Lyons WE: BDNF promotes the regenerative sprouting, but not survival, of injured serotonergic axons in the adult rat brain. J Neurosci 2000, 20:771-782.

10. Salichon N, Gaspar P, Upton AL, Picaud S, Hanoun N, Hamon M, De Maeyer E, Murphy DL, Mossner R, Lesch KP, Hen R, Seif I: Excessive activation of serotonin (5-HT) $1 \mathrm{~B}$ receptors disrupts the formation of sensory maps in monoamine oxidase a and 5-ht transporter knock-out mice. J Neurosci 2001, 21:884-96.

11. Bradley CC, Blakely RD: Alternative splicing of the human serotonin transporter gene. J Neurochem 1997, 69:1356-1367.

12. Heinz A, Braus DF, Smolka MN, Wrase J, Puls I, Hermann D, Klein S, Grüsser SM, Flor H, Schumann G, Mann K, Büchel C: Amygdala-prefrontal coupling depends on a genetic variation of the serotonin transporter. Nat Neurosci 2005, 8:20-21.

13. Pezawas $L$, Meyer-Lindenberg A, Drabant EM, Verchinski BA, Munoz KE, Kolachana BS, Egan MF, Mattay VS, Hariri AR, Weinberger DR: 5-HTTLPR polymorphism impacts human cingulate-amygdala interactions: a genetic susceptibility mechanism for depression. Nat Neurosci 2005, 8:828-834.

14. Watson C, Hoeft F, Garrett AS, Hall SS, Reiss AL: Aberrant brain activation during gaze processing in boys with fragile X syndrome. Arch Gen Psychiatry 2008, 65:1315-1323.

15. Meyer-Lindenberg A, Hariri AR, Munoz KE, Mervis CB, Mattay VS, Morris CA, Berman KF: Neural correlates of genetically abnormal social cognition in Williams syndrome. Nat Neurosci 2005, 8:991-993.

16. Lesch KP, Bengel D, Heils A, Sabol SZ, Greenberg BD, Petri S, et al: Association of anxiety-related traits with a polymorphism in the serotonin transporter gene regulatory region. Science 1996, 274:1527-1531.

17. Hu X, Oroszi G, Chun J, Smith TL, Goldman D, Schuckit MA: An expanded evaluation of the relationship of four alleles to the level of response to alcohol and the alcoholism risk. Alcohol Clin Exp Res 2005, 29:8-16.

18. Fallgatter AJ, Bartsch AJ, Herrmann MJ: Electrophysiological measurements of anterior cingulate function. J Neural Transm 2002, 109:977-988.

19. Canli T, Lesch KP: Long story short: the serotonin transporter in emotion regulation and social cognition. Nat Neurosci 2007, 10:1103-1109.

20. MacKenzie A, Quinn JA: serotonin transporter gene intron 2 polymorphic region, correlated with affective disorders, has allele-dependent 
differential enhancer-like properties in the mouse embryo. Proc Natl Acad Sci USA 1999, 96:15251-15255.

21. Battersby S, Ogilvie AD, Blackwood DH, Shen S, Muqit MM, Muir WJ, Teague P, Goodwin GM, Harmar AJ: Presence of multiple functional polyadenylation signals and a single nucleotide polymorphism in the $3^{\prime}$ untranslated region of the human serotonin transporter gene. $J$ Neurochem 1999, 72:1384-1388.

22. Ren-Patterson RF, Cochran LW, Holmes A, Sherrill S, Huang SJ, Tolliver T, Lesch KP, Lu B, Murphy DL: Loss of brain-derived neurotrophic factor gene allele exacerbates brain monoamine deficiencies and increases stress abnormalities of serotonin transporter knockout mice. J Neurosci Res 2005, 79:756-771.

23. Daws LC, Munn JL, Valdez MF, Frosto-Burke T, Hensler JG: Serotonin transporter function, but not expression, is dependent on brain-derived neurotrophic factor (BDNF): in vivo studies in BDNF-deficient mice. $J$ Neurochem 2007, 101:641-651.

24. Siuciak JA, Boylan C, Fritsche M, Altar CA, Lindsay RM: BDNF increases monoaminergic activity in rat brain following intracerebroventricular or intraparenchymal administration. Brain Res 1996, 710:11-20.

25. Yamada MK, Nakanishi K, Ohba S, Nakamura T, Ikegaya Y, Nishiyama N, Matsuki N: Brain-derived neurotrophic factor promotes the maturation of GABAergic mechanisms in cultured hippocampal neurons. J Neurosci 2002, 22:7580-7585.

26. Liu QR, Walther D, Drgon T, Polesskaya O, Lesnick TG, Strain KJ, de Andrade M, Bower JH, Maraganore DM, Uhl GR: Human brain derived neurotrophic factor (BDNF) genes, splicing patterns, and assessments of associations with substance abuse and Parkinson's Disease. Am J Med Genet B Neuropsychiatr Genet 2005, 134:93-103.

27. Egan MF, Kojima M, Callicott JH, Goldberg TE, Kolachana BS, Bertolino A, Zaitsev E, Gold B, Goldman D, Dean M, Lu B, Weinberger DR: The BDNF val66 met polymorphism affects activity-dependent secretion of BDNF and human memory and hippocampal function. Cell 2003, 112:257-269.

28. Miyajima F, Ollier W, Mayes A, Jackson A, Thacker N, Rabbitt P, Pendleton N, Horan M, Payton A: Brain-derived neurotrophic factor polymorphism Val66 Met influences cognitive abilities in the elderly. Genes Brain Behav 2008, 7:411-417.

29. Singh VK, Singh EA, Warren RP: Hyperserotoninemia and serotonin receptor antibodies in children with autism but not mental deficiency. Biol Psychiatry 1997, 41:753-755

30. Nelson KB, Grether JK, Croen LA, Dambrosia JM, Dickens BF, Jelliffe LL, Hansen RL, Phillips TM: Neuropeptides and neurotrophins in neonatal blood of children with autism or mental deficiency. Ann Neurol 2001, 49:597-606.

31. Miyazaki K, Narita N, Sakuta R, Miyahara T, Naruse H, Okado N, Narita M: Serum neurotrophin concentrations in autism and mental deficiency: a pilot study. Brain Dev 2004, 26:292-295.

32. Wendland JR, Martin BJ, Kruse MD, Lesch KP, Murphy DL: Simultaneous genotyping of four functional loci of human SLC6A4, with a reappraisal of 5-HTTLPR and rs25531. Mol Psychiatry 2006, 113:224-226.

33. Cook EH Jr, Courchesne R, Lord C, Cox NJ, Yan S, Lincoln A, Haas R, Courchesne E, Leventhal BL: Evidence of linkage between the serotonin transporter and autistic disorder. Mol Psychiatry 1997, 2:247-250.

34. Bland JM, Altman DG: Statistics Notes: The odds ratio. BMJ 2000, 320:1468.

35. Martinowich K, LU B: Interaction between BDNF and serotonin: role in mood disorders. Neuropsychopharmacology 2008, 33:73-83.

36. Heils A, Teufel A, Petri S, Stöber G, Riederer P, Bengel D, Lesch KP: Allelic variation of human serotonin transporter gene expression. J Neurochem 1996, 66:2621-2624.

37. Collier DA, Stöber G, Li T, Heils A, Catalano M, Di Bella D, Arranz MJ, Murray RM, Vallada HP, Bengel D, Müller CR, Roberts GW, Smeraldi E, Kirov G, Sham P, Lesch KP: A novel functional polymorphism within the promoter of the serotonin transporter gene: possible role in susceptibility to affective disorders. Mol Psychiatry 1996, 1:453-460

38. Eckert D, Buhl S, Weber $S$, Jager R, Schorle H: The AP-2 family of transcription factors. Genome Biol 2005, 6:246

39. Hu XZ, Lipsky RH, Zhu G, Akhtar LA, Taubman J, Greenberg BD, Xu K, Arnold PD, Richter MA, Kennedy JL, Murphy DL, Goldman D: Serotonin transporter promoter gain-of-function genotypes are linked to obsessive-compulsive disorder. Am J Hum Genet 2006, 78:815-826.

40. Harris SE, Fox H, Wright AF, Hayward C, Starr JM, Whalley $\sqcup$, Deary IJ: The brain-derived neurotrophic factor Val66 Met polymorphism is associated with age-related change in reasoning skills. Mol Psychiatry 2006, 11:505-513.

41. Pruunsild P, Kazantseva A, Aid T, Palm K, Timmusk T: Dissecting the human BDNF locus: bidirectional transcription, complex splicing, and multiple promoters. Genomics 2007, 397-406.

42. Kaufman J, Yang BZ, Douglas-Palumberi H, Grasso D, Lipschitz D, Houshyar S, Krystal JH, Gelernter J: Brain-derived neurotrophic factor-5HTTLPR gene interactions and environmental modifiers of depression in children. Biol Psychiatry 2006, 59:673-680.

43. Hünnerkopf R, Strobel A, Gutknecht L, Brocke B, Lesch KP: Interaction between BDNF Val66 Met and dopamine transporter gene variation influences anxiety-related traits. Neuropsychopharmacology 2007, 32:2552-2560

44. Frodl T, Schüle C, Schmitt G, Born C, Baghai T, Zill P, Bottlender R, Rupprecht R, Bondy B, Reiser M, Möller HJ, Meisenzahl EM: Association of the brain-derived neurotrophic factor Val66 Met polymorphism with reduced hippocampal volumes in major depression. Arch Gen Psychiatry 2007, 64:410-416.

45. Philibert R, Madan A, Andersen A, Cadoret R, Packer H, Sandhu H: Serotonin transporter MDNA levels are associated with the methylation of an upstream CpG island. Am J Med Genet B Neuropsychiatr Genet 2007, 144:101-105.

46. Bredy TW, Wu H, Crego C, Zellhoefer J, Sun YE, Barad M: Histone modifications around individual BDNF gene promoters in prefrontal cortex are associated with extinction of conditioned fear. Learn Mem 2007, 14:268-276.

\section{Pre-publication history}

The pre-publication history for this paper can be accessed here:http://www biomedcentral.com/1471-2350/11/30/prepub

doi:10.1186/1471-2350-11-30

Cite this article as: Tabagh et al: Study of the serotonin transporter (SLC6A4) and BDNF genes in French patients with non syndromic mental deficiency. BMC Medical Genetics 2010 11:30.

\section{Submit your next manuscript to BioMed Central and take full advantage of:}

- Convenient online submission

- Thorough peer review

- No space constraints or color figure charges

- Immediate publication on acceptance

- Inclusion in PubMed, CAS, Scopus and Google Scholar

- Research which is freely available for redistribution

Submit your manuscript at www.biomedcentral.com/submit
C Biomed Central 